\title{
Birds use structural properties when selecting materials for different parts of their nests
}

\author{
Lucia E. Biddle $^{1} \cdot$ D. Charles Deeming ${ }^{1} \cdot$ Adrian M. Goodman $^{1}$
}

Received: 19 September 2017 / Revised: 16 May 2018 / Accepted: 8 June 2018 / Published online: 20 June 2018

(c) The Author(s) 2018

\begin{abstract}
Bird nests can have various roles but all act as the location for incubation, so at least have to serve to hold and support the incubating bird and its clutch of eggs. Nest construction is species specific and the use of materials varies between different parts of the nest. At present we know very little about the role that these materials play in the structural characteristics of the nest. This study examined materials from deconstructed nests from four species of thrush (Turdidae) and two species of finch (Fringillidae) that all constructed nests made of woody stems. It was hypothesised that structural properties would vary within the different regions of a nest, with thicker and stronger materials being found in parts of the nest needing the most support. Secondly, it was predicted that structural properties would vary little between nests of members of the same family, but would be quite different between nests of different families. Nests were deconstructed to quantify the materials used in the cup lining, and the upper and lower parts of the outer nest. The 20 thickest pieces of material were selected from each nest part and for each piece, and their diameter and mass quantified. Each piece was then subjected to a three-point bending test using an Instron universal testing machine to determine its rigidity and bending strength. Placement of materials in the nest was non-random in all species. The materials used in the outer part of the nest were thicker, stronger and stiffer than those materials found in the cup lining. The extent to which these structural properties varied between families depended on where the material was taken from the nest. Both strength and rigidity strongly positively correlated with the diameter of the piece of material. We hypothesise that birds are not directly aware of the structural properties of the material per se but rather assess diameter and mass of the material when they pick it up by the bill. Using this information they decide on whether the piece is suitable for that appropriate stage of nest construction.
\end{abstract}

Keywords Biomechanics $\cdot$ Bird nest construction $\cdot$ Fringillidae $\cdot$ Rigidity $\cdot$ Strength $\cdot$ Turdidae

\section{Zusammenfassung}

Vögel nutzen Struktureigenschaften bei der Materialauswahl für verschiedene Nestbereiche.

Vogelnester können vielfältige Funktionen erfüllen, aber alle dienen als Ort der Bebrütung und müssen so zumindest groß und stabil genug für den brütenden Vogel und das Gelege sein. Die Nestbauweise ist artspezifisch, und die Materialverwendung unterscheidet sich zwischen den einzelnen Nestbereichen. Derzeit wissen wir nur sehr wenig über die Bedeutung, welche diese Materialien für die strukturellen Eigenschaften des Nestes haben. In dieser Studie wurden Materialien aus zerlegten Nestern von vier Drossel- (Turdidae) und zwei Finkenarten (Fringillidae) untersucht, die alle Nester aus holzigen Stängeln bauen. Unsere Hypothese besagte, dass sich die strukturellen Eigenschaften verschiedener Nestbereiche dahingehend unterscheiden sollten, dass sich dickeres und stabileres Material in den Nestteilen befindet, welche die größte Stabilität brauchen. Zweitens gingen wir von der Erwartung aus, dass sich die strukturellen Eigenschaften zwischen Mitgliedern derselben Vogelfamilie nur wenig unterscheiden, von Familie zu Familie jedoch sehr verschieden sein sollten. Die Nester

Communicated by F. Bairlein.

Electronic supplementary material The online version of this article (https://doi.org/10.1007/s10336-018-1571-y) contains supplementary material, which is available to authorized users.

Extended author information available on the last page of the article 
wurden zerlegt, um die Materialmengen zu quantifizieren, die für die Auspolsterung der Nestmulde sowie für die oberen und unteren Bereiche des äußeren Nests verwendet wurden. Aus jedem Nestbereich wählten wir die 20 dicksten Materialteile aus und bestimmten für jedes davon Durchmesser und Masse. Dann wurde jedes Stück einem 3-Punkt-Biegeversuch mit einer Instron-Universalprüfmaschine unterzogen, um dessen Starrheit und Biegefestigkeit zu ermitteln. Die Anordnung der Materialien im Nest war bei allen Arten nicht zufallsverteilt. Die im äußeren Nestbereich verbauten Materialien waren dicker, stabiler und starrer als die Polstermaterialien in der Nestmulde. Das Ausmaß, zu dem diese Struktureigenschaften sich zwischen den Familien unterschieden, hing vom Nestbereich ab, aus dem das Material entnommen wurde. Sowohl Stabilität als auch Starrheit zeigten eine starke positive Korrelation mit dem Durchmesser des Materialteiles. Wir stellen die Hypothese auf, dass sich die Vögel der strukturellen Eigenschaften des Materials nicht per se bewusst sind, sondern stattdessen eher Durchmesser und Masse des Materials erfassen, wenn sie es mit dem Schnabel aufnehmen. Anhand dieser Informationen entscheiden sie dann, ob dieses Stück für die betreffende Phase des Nestbaus geeignet ist.

\section{Introduction}

Birds use a wide variety of plant, animal and artificial materials to construct their nests (Hansell 2000). Whilst the nest itself is primarily where eggs are incubated (Deeming 2016) it is suggested that they have a range of other roles associated with reproduction, and perhaps even lifetime fitness (Moreno 2012; Mainwaring et al. 2014a). Birds select materials during nest construction for a variety of reasons (Deeming and Mainwaring 2015), including sexual signalling (Dubiec et al. 2013; Tomás et al. 2013), defence from parasites or pathogens (Dubiec et al. 2013), camouflage (Kull 1977; Bailey et al. 2015), insulation (Hilton et al. 2004; Dhandhukia and Patel 2012; Mainwaring et al. 2014b) or for their structural role (Bailey et al. 2014; Biddle et al. 2015, 2017). Whether these materials are deliberately selected for specific roles has yet to be fully investigated, but it is known that variation in a particular type of material reflects its availability within the local environment (Moreno et al. 2008; Surgey et al. 2012; Álvarez et al. 2013; Cantarero et al. 2015; Briggs and Deeming 2016).

Recent studies have tried to determine the factors that affect nest construction both using captive species and by examining nests from the field, particularly in light of the structural properties of the materials. Captive Zebra Finches Taeniopygia guttata have been used to demonstrate that the structural properties of artificial materials (string) as well as the experience of the bird influence the materials chosen, with stiffer string appearing to be the more effective building material (Bailey et al. 2014). Additionally, captive birds also show an apparent sensitivity to the length of the string (Muth and Healy 2014). Wild birds also appear to select materials which play an important mechanical role in construction. Common House Martins Delichon urbicum have been shown to enhance the mechanical behaviour of mudbased nesting materials, particularly in compression, with the addition of polysaccharide/sugars obtained from abundant plant fruits (Silva et al. 2010). In the nests of Common
Blackbirds Turdus merula plant-derived materials in the outer nest were found to be thicker, stronger and more rigid compared to the materials present within the structural wall and the cup lining (Biddle et al. 2015). A similar pattern was observed in the mechanical properties of materials used in the various parts of the nests of Eurasian Bullfinch Pyrrhula pyrrhula (hereafter 'Bullfinch') (Biddle et al. 2017). The materials used by Bullfinches in the outer nest were thicker and stronger than those used by the much heavier Common Blackbird, which may reflect the absence of an internal mud cup in the Bullfinch nests (Biddle et al. 2017). These reports suggest that these birds may have some level of awareness of where and when to place certain materials in order to create a nest structure, although this has yet to be tested experimentally (Biddle et al. 2017).

Other animals have also been shown to use materials in a non-random manner during the construction of nests and other structures. Orang-utans Pongo sp. build nests in trees that act as sleeping beds. They select stronger, more rigid materials for the outer 'structural' part of the nest compared to the weaker and more flexible materials used to construct the cup lining (Van Casteren et al. 2012). Irrespective of the availability of tree species in one study, Eurasian Beavers Castor fiber largely used poplars Populus and willow Salix branches in building their lodges (Fustec and Cormier 2007). A second study showed that beavers building a dam restricted themselves to using alder Alnus branches that were $1.5-3.5 \mathrm{~cm}$ in diameter (Barnes and Mallik 1996).

To date, detailed descriptions of the types of materials used in nest construction are limited to only a few bird species (Deeming and Mainwaring 2015; Biddle et al. 2018) and the structural properties of these are largely unknown. Studies of the structural properties of nest materials are rare (Silva et al. 2010; Biddle et al. 2015, 2017; Bailey et al. 2016), so little is known about whether birds are generally selective of nest materials based on their biomechanical properties. It is also not known whether the species studied to date are representative of other species of similar size. 
This study determined whether the structural components of nests built by four members of the Turdidae and the Hawfinch Coccothraustes coccothraustes (Fringillidae) vary between different nest regions as well as between species. Previously published data from Bullfinch nests (Biddle et al. 2017) were included in the analysis to allow for intra-family comparison with the Hawfinch. It was hypothesised that the structural properties would vary between the different structural regions. It was considered that the nest walls and base would need to offer structural support for the whole nest (Hansell 2000), so it was predicted that the outer nest would be composed of thicker, stronger and more rigid materials than the cup lining. Furthermore, qualitative descriptions of the materials used in nests (Ferguson-Lees et al. 2011) suggested that the structural properties of the materials would not vary greatly between members of the same family but would be more different between the two families.

\section{Methods}

Mechanical analysis was carried out on the nests of four members of the Turdidae: Common Blackbird $(n=11)$, Mistle Thrush Turdus viscivorus $(n=11)$, Song Thrush Turdus philomelos $(n=16)$, and Ring Ouzel Turdus torquatus $(n=9)$. Additionally, four Hawfinch nests, which like Bullfinch nests are mainly constructed of woody stems, were also subjected to mechanical analysis and compared with data for Bullfinch ( $n=13)$ nests collected using the same methodology (Biddle et al. 2017). Nests were supplied by members of the public who partake in the British Trust for Ornithology's Nest Record Scheme. Nests of known provenance were collected after the breeding season was completed and were shipped to the University of Lincoln from a variety of locations across the UK. In Lincoln the nests were frozen at $-20^{\circ} \mathrm{C}$ to kill biting invertebrates (Britt and Deeming 2011) before being air-dried and stored in plastic bags in cardboard boxes at room temperature (Biddle et al. 2017, 2018).

Nests were first deconstructed into their component parts (see Biddle et al. 2018) and separated into four distinct regions: the top and base of the outer nest, the internal 'mud' cup (thrushes), and the cup lining. All thrushes construct a cup from mud mixed with plant materials except for the Song Thrush that uses wood pulp to build the cup (Biddle et al. 2018). Hereafter, we refer to the 'mud cup' but whilst doing so bear in mind this difference. The base of the outer nest was considered to comprise those materials found below the bottom of the mud cup, whereas the top of the outer nest was considered to comprise those materials found alongside the mud cup (Biddle et al. 2017, 2018). Each region of the nest was then carefully separated into its construction elements and these were then arranged in order of diameter within each region. The 20 thickest samples from each region were then selected for mechanical testing (Biddle et al. 2017). These included all the structurally important samples for each region, which were defined as those with a diameter greater than $0.3 \mathrm{~mm}$. Following the methodology of Biddle et al. (2017) samples for mechanical testing were conditioned in a Sanyo MLR-351H environmental chamber for 2 weeks at $23{ }^{\circ} \mathrm{C}$ with $50 \%$ humidity, until they had equilibrated to a constant weight. All testing of materials was performed within $12 \mathrm{~h}$ after their removal from the cabinet.

Three-point bending tests were carried out using an Instron universal testing machine (model 4443) fitted with a $100 \mathrm{~N}$ load cell. The midpoint diameter of each sample was measured using Mitutoyo digital callipers (accuracy of $\pm 0.02 \mathrm{~mm}$ ) and samples were placed between two supports which were set apart at a distance of 20 times the midpoint diameter to reduce any effects of shear (Vincent 1992). A pushing probe of 5-mm radius was lowered until it just touched the sample, and then the crosshead was lowered at a rate of $10 \mathrm{~mm} \mathrm{~min}^{-1}$ causing the sample to bend before eventually failing. A graph of force versus displacement was produced using an interfaced computer which allowed the calculation of the structural properties of the sample using commonly used equations (Gordon 1978). The bending strength, or maximum bending moment ( $M$ in newton metres; Eq. 1) was calculated using the following expression:

$M=F_{\max } L / 4$,

where $F_{\max }$ is the maximum force (Newtons) a sample will withstand before it fails, and $L$ is the distance between the supports in metres. The bending rigidity (EI; Newton metre squared; Eq. 2), the resistance of the beam to curvature is given by:

$\mathrm{EI}=L^{3}\left(\frac{\mathrm{d} F}{\mathrm{~d} \delta}\right) / 48$,

where $\frac{\mathrm{d} F}{\mathrm{~d} \delta}$ is the initial slope of the force displacement curve.

Around $3.5 \%$ of samples slipped from their supports during testing; these were excluded from the subsequent analysis, which resulted in unequal sample sizes. After mechanical testing the length and weight of each sample was measured; the mass was then normalised by dividing by the length and was expressed in grams per millimetre.

The analysis was carried out using a single datum, which was the mean of the samples within a region for each nest, and sample size equated to the number of nests. The data for all variables were $\log _{10}$-transformed before general linear mixed modelling in Minitab (version 17) was carried out to compare the effects of species and region as fixed factors whilst controlling for nest, nested within species, as a random factor. Song Thrush nests lack any nest lining (Biddle et al. 2018) and initial analysis was carried out first using all 
nest regions (cup lining, base, and top of outer nest) of Ring Ouzel, Mistle Thrush and Blackbird nests. Further analysis was carried out on the top and base of the outer nest so as to include Song Thrush nests. Analysis for the two species of finch nests included all three regions. The analysis did not include phylogenetic control because it was felt this would add very little to our understanding of the results because the number of species was small and within a family the species were all closely related.

\section{Results}

For all four species of thrush studied, most of the nest materials were found to be no thicker than approximately $1.3 \mathrm{~mm}$ in the cup lining, $1.9 \mathrm{~mm}$ in the base of the outer nest and $2.3 \mathrm{~mm}$ in the top of the outer nest. The nests for all species had thicker, stronger, more rigid and heavier materials in the outer nest compared to the materials in the cup lining (Fig. 1). Furthermore, the top of the outer nest contained materials that were thicker, stronger, more rigid and had a
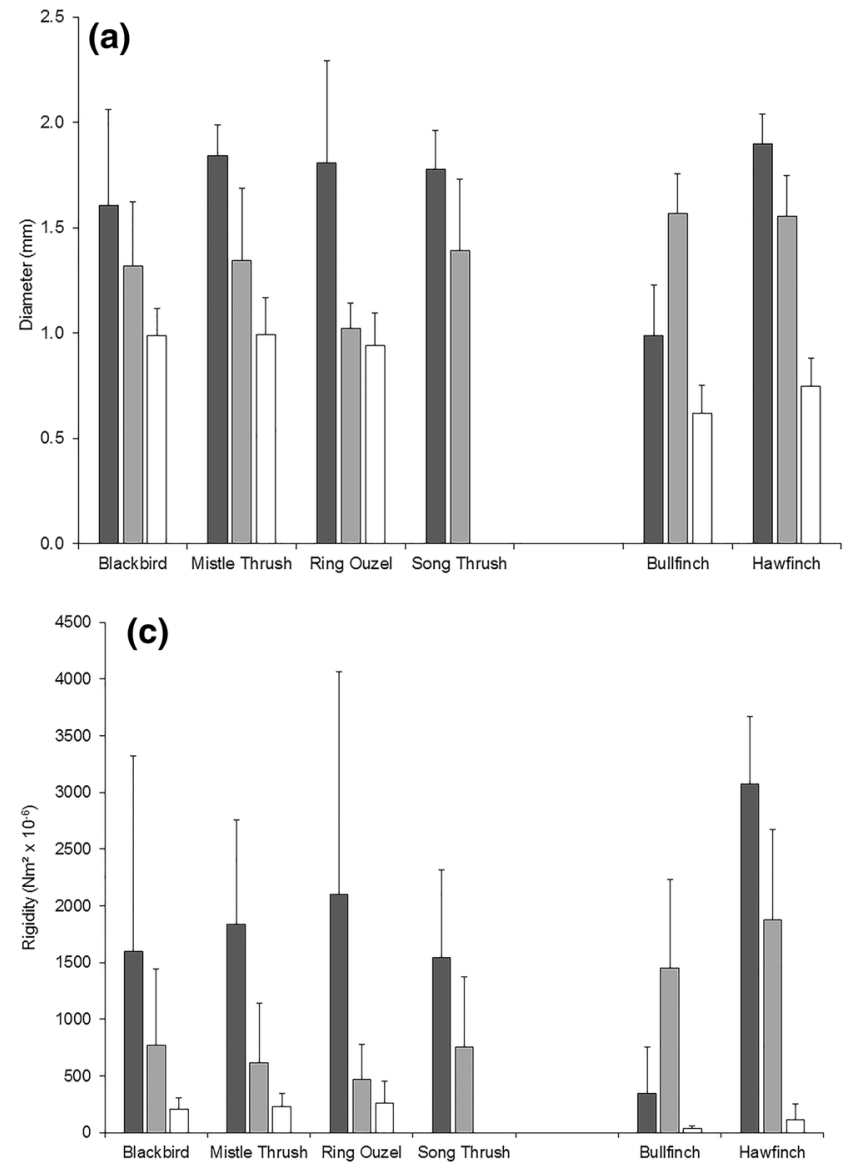

Fig. 1 Mean (+SD) diameter (a; mm), bending strength (b; $\left.\mathrm{Nm} \times 10^{-3}\right)$, rigidity $\left(\mathbf{c} ; \mathrm{Nm}^{2} \times 10^{-6}\right)$ and normalised mass $(\mathbf{d}$; $\mathrm{g} \mathrm{mm}^{-1}$ ) of materials present within the top of the outer nest (dark greater weight than the materials within the base of the outer nest (Fig. 1). No significant difference was observed between the four species of thrush for the diameter, bending strength, rigidity and normalised mass of materials obtained from the top and base of the outer nest. By contrast, significant differences were observed between the sample regions within the nest, e.g. the diameter of samples was significantly greater in the outer nest than the cup lining (Table 1). There was no significant interaction between species and region (Table 1). A similar pattern was seen when the materials in the cup lining were compared to the materials from the top and base of the outer nest for Ring Ouzels, Blackbirds and Mistle Thrushes (Table 1). Therefore, in each of the four thrush species the top of the outer nest was significantly thicker, stronger, more rigid and contained heavier elements than the base of the nest which in turn in Ring Ouzel, Mistle thrush and Blackbird nests contains thicker, stronger, more rigid and heavier elements than the cup lining (Fig. 1, Table 1).

In nests of both finch species, the base of the outer nest contained materials no greater than approximately $1.7 \mathrm{~mm}$ in diameter and the cup lining $1.0 \mathrm{~mm}$ in diameter. Within
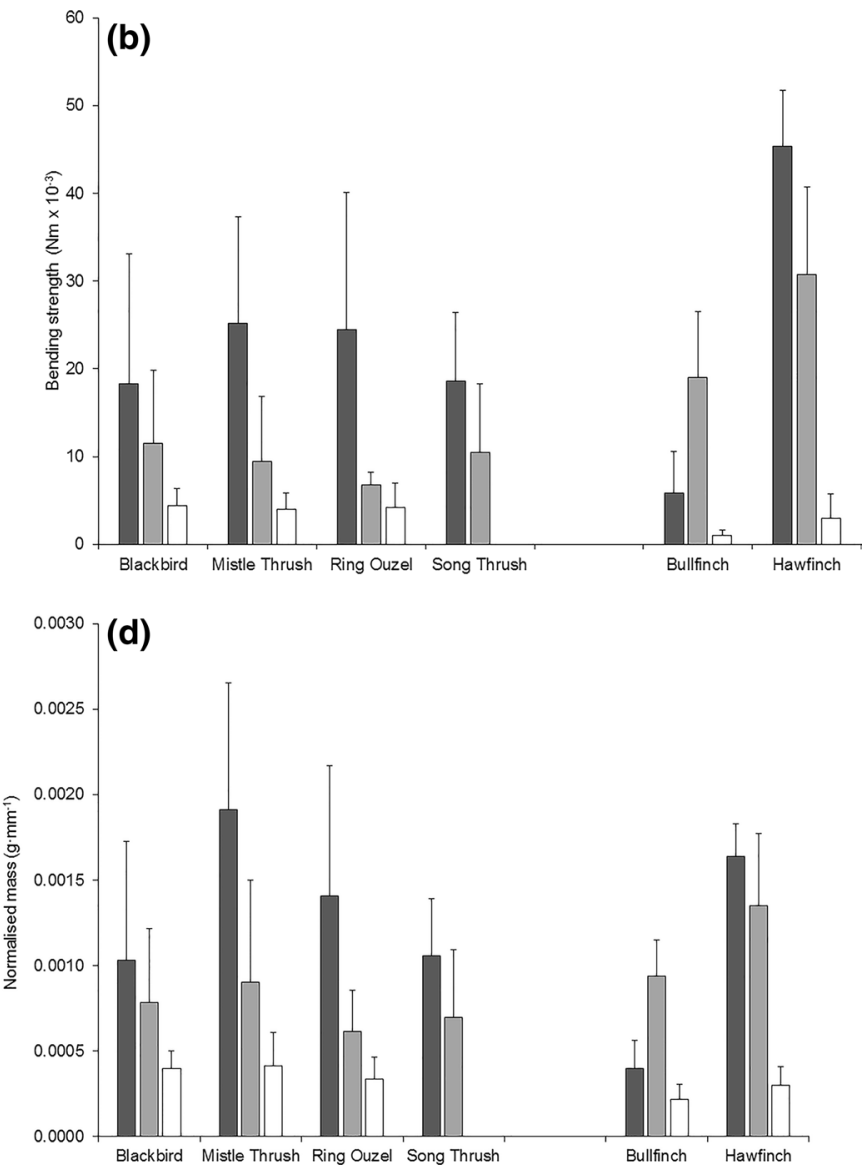

grey), base of the outer nest (light grey) and the cup lining (white) for four species of thrush and two species of finch 
Table 1 Results of general linear mixed modelling to examine the effect of region within the nest for various structural measures whilst controlling for nest nested within species as a random factor in the model

\begin{tabular}{|c|c|c|c|c|c|c|}
\hline & Variable & $d f$ & Diameter (mm) & Rigidity $\left(\mathrm{Nm}^{2} \times 10^{-6}\right)$ & $\begin{array}{l}\text { Bending } \\
\text { strength } \\
\left(\mathrm{Nm} \times 10^{-3}\right)\end{array}$ & Normalised mass $\left(\mathrm{g} \mathrm{mm}^{-1}\right)$ \\
\hline \multirow{5}{*}{$\begin{array}{l}\text { Thrush-comparison } \\
\text { between the two regions } \\
\text { of the outer nest and the } \\
\text { cup lining (three species) }\end{array}$} & Species & 2,36 & $1.53(0.227)$ & $0.86(0.431)$ & $0.60(0.555)$ & $2.15(0.131)$ \\
\hline & Region & 2,36 & $53.06(<0.001)$ & $50.43(<0.001)$ & $54.02(<0.001)$ & $51.59(<0.001)$ \\
\hline & Species $\times$ Region & 4,36 & $0.78(0.543)$ & $0.30(0.875)$ & $0.80(0.533)$ & $1.75(0.160)$ \\
\hline & Nest (Species) & 28,36 & $0.88(0.633)$ & $1.43(0.155)$ & $1.53(0.114)$ & $2.03(0.023)$ \\
\hline & $R^{2}(\%)$ & & 79.70 & 80.60 & 81.86 & 83.26 \\
\hline \multirow{5}{*}{$\begin{array}{l}\text { Thrush-comparison } \\
\text { between the two regions } \\
\text { of the outer nest (four } \\
\text { species) }\end{array}$} & Species & 3,23 & $1.93(0.135)$ & $1.24(0.303)$ & $1.30(0.283)$ & $2.85(0.045)$ \\
\hline & Region & 1,23 & $49.97(<0.001)$ & $31.66(<0.001)$ & $28.06(<0.001)$ & $20.32(<0.001)$ \\
\hline & Species $\times$ Region & 3,23 & $0.54(0.662)$ & $0.14(0.938)$ & $0.04(0.987)$ & $0.02(0.996)$ \\
\hline & Nest (Species) & 43,23 & $2.27(0.019)$ & $2.02(0.037)$ & $2.23(0.021)$ & $2.53(0.010)$ \\
\hline & $R^{2}(\%)$ & & 88.05 & 85.53 & 86.56 & 87.78 \\
\hline \multirow{5}{*}{$\begin{array}{l}\text { Finch-comparison } \\
\text { between the two regions } \\
\text { of the outer nest and the } \\
\text { cup lining }\end{array}$} & Species & 1,29 & $13.89(0.002)$ & $16.36(0.001)$ & $28.84(<0.001)$ & $28.19(<0.001)$ \\
\hline & Region & 2,29 & $143.68(<0.001)$ & $78.65(<0.001)$ & $75.17(<0.001)$ & $104.30(<0.001)$ \\
\hline & Species $\times$ Region & 2,29 & $18.14(<0.001)$ & $8.31(0.001)$ & $6.76(0.004)$ & $16.24(<0.001)$ \\
\hline & Nest (Species) & 15,29 & $3.58(0.002)$ & $1.96(0.059)$ & $1.56(0.149)$ & $2.56(0.014)$ \\
\hline & $R^{2}(\%)$ & & 95.07 & 91.07 & 90.98 & 93.48 \\
\hline
\end{tabular}

Values are $F$-values with $d f$ shown with $p$-values in parentheses

the top of the Bullfinch nests, materials were approximately $1.0 \mathrm{~mm}$, whilst the materials in the top of the Hawfinch nests were approximately $1.8 \mathrm{~mm}$ in diameter. Hawfinch nests were composed of a base constructed of thicker, stronger, more rigid and heavier materials than the materials in the top of the outer nest, which in turn was thicker, stronger, more rigid and heavier than the materials in the cup (Fig. 1). Like Hawfinch nests, Bullfinch nests were composed of a cup lining constructed of the weakest, thinnest and least rigid materials. By contrast, the base of the outer nest, not the top, was found to be constructed of the thickest, strongest, most rigid and heaviest material (Fig. 1). All variables were found to be significantly different between the two species as well as between the different regions within each nest, and there was a significant species-region interaction, which indicated that the properties exhibited by materials from different parts of the nests were species dependent (Table 1).

Significant positive correlations were observed between all of the four variables measured, i.e. diameter, bending strength, rigidity and normalised mass (Table 2; Fig. 2). Not surprisingly, thicker samples weighed more, were more rigid and stronger, so further analysis determined the effect of region and species on the other three variables whilst controlling for diameter as a covariate.

Materials in the base and top of the outer nest for all four thrushes showed no effect of sample region for rigidity, bending strength or species and the species-region interaction still showed no significance (Table 3). By contrast, a significant difference was found between species for the weight of materials, with Mistle Thrush nests having heavier materials per unit length whilst Song Thrush nests contained the lightest materials (Fig. 3). When comparing the parts of the outer nest with the cup lining, diameter was again found to be a significant covariate whilst other factors were non-significant (Table 3).

For finch nests, sample region, species and the speciesregion interaction for rigidity and bending strength were non-significant, whilst diameter was a highly significant covariate (Table 3 ). The weight of the materials within the
Table 2 Spearman's rank correlation $\rho$-values ( $p$-value) comparing the mechanical properties and normalised mass of all materials from all sampling regions combined for the nests of thrushes and finches

\begin{tabular}{llll}
\hline & Diameter $(\mathrm{mm})$ & Rigidity $\left(\mathrm{Nm}^{2} \times 10^{-6}\right)$ & $\begin{array}{l}\text { Bending } \\
\text { strength } \\
\left(\mathrm{Nm} \times 10^{-3}\right)\end{array}$ \\
\hline Rigidity $\left(\mathrm{Nm}^{2} \times 10^{-6}\right)$ & $0.943(<0.001)$ & & \\
$\begin{array}{l}\text { Bending strength }\left(\mathrm{Nm} \times 10^{-3}\right) \\
\begin{array}{l}\text { Normalised mass } \\
\left(\mathrm{g} \mathrm{mm}^{-1}\right)\end{array}\end{array}$ & $0.929(<0.001)$ & $0.983(<0.001)$ & $0.928(<0.001)$ \\
\hline
\end{tabular}


Fig. 2 Relationship between diameter and the rigidity of materials used in the construction of nests for all species and regions combined. Line represents the line of best fit to indicate the trend. Note the $\log _{10}$ scales on the axes

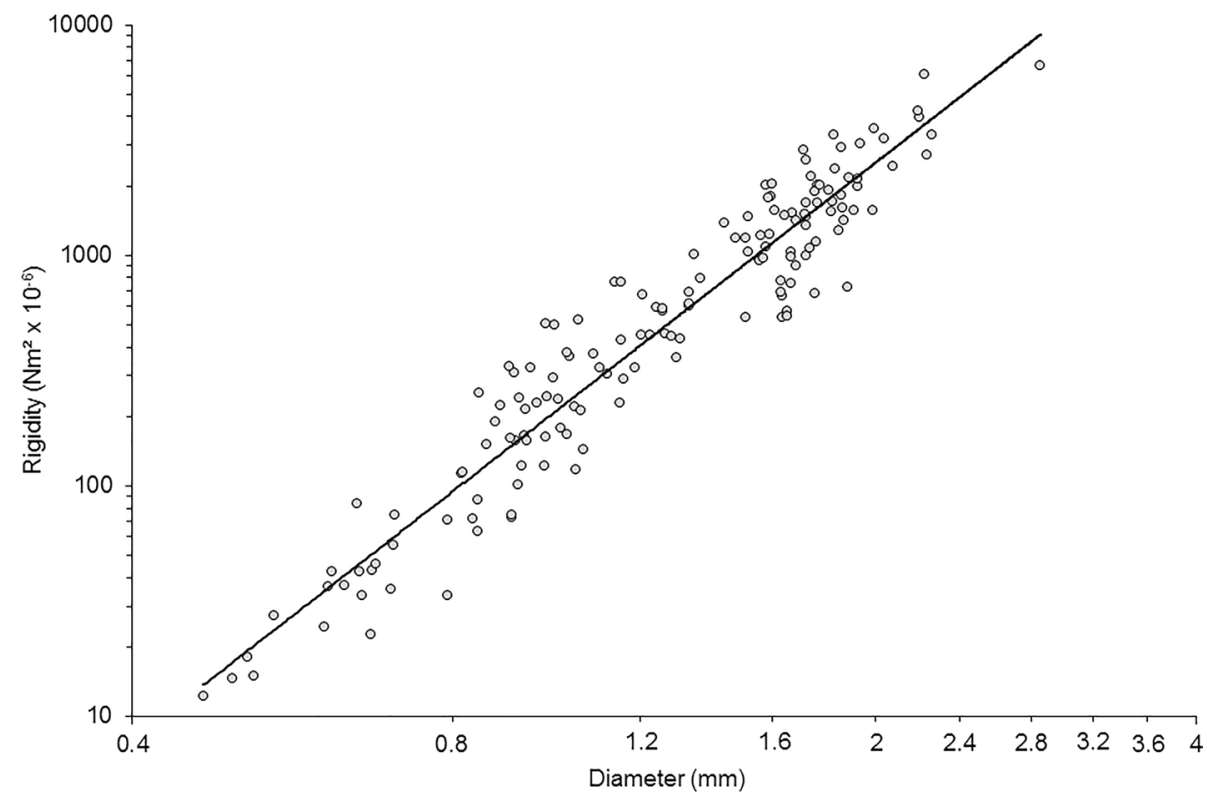

Table 3 Results of general linear mixed modelling to examine the effect of region within the nest for various structural measures whilst controlling for nest nested within species as a random factor in the model and adding diameter as a covariate

\begin{tabular}{|c|c|c|c|c|c|}
\hline & Variable & $d f$ & Rigidity $\left(\mathrm{Nm}^{2} \times 10^{-6}\right)$ & $\begin{array}{l}\text { Bending } \\
\text { strength } \\
\left(\mathrm{Nm} \times 10^{-3}\right)\end{array}$ & Normalised mass $\left(\mathrm{g} \mathrm{mm}^{-1}\right)$ \\
\hline \multirow{6}{*}{$\begin{array}{l}\text { Thrush-comparison between the two } \\
\text { regions of the outer nest and the cup } \\
\text { lining (three species) }\end{array}$} & Diameter (covariate) & 1,35 & $86.28(<0.001)$ & $78.13(<0.001)$ & $55.49(<0.001)$ \\
\hline & Species & 2,35 & $1.33(0.274)$ & $0.94(0.397)$ & $1.68(0.199)$ \\
\hline & Region & 2,35 & $1.01(0.375)$ & $2.05(0.144)$ & $2.73(0.079)$ \\
\hline & Species $\times$ Region & 4,35 & $0.17(0.955)$ & $0.63(0.644)$ & $1.89(0.134)$ \\
\hline & Nest (Species) & 28,35 & $1.07(0.422)$ & $1.56(0.105)$ & $2.26(0.012)$ \\
\hline & $R^{2}(\%)$ & & 94.40 & 94.39 & 93.53 \\
\hline \multirow{6}{*}{$\begin{array}{l}\text { Thrush-comparison between the two } \\
\text { regions of the outer nest (four species) }\end{array}$} & Diameter (covariate) & 1,22 & $105.67(<0.001)$ & $100.49(<0.001)$ & $44.84(<0.001)$ \\
\hline & Species & 3,22 & $1.42(0.244)$ & $2.58(0.063)$ & $5.27(0.003)$ \\
\hline & Region & 1,22 & $1.13(0.299)$ & $2.05(0.166)$ & $1.51(0.233)$ \\
\hline & Species $\times$ Region & 3,22 & $0.84(0.485)$ & $1.38(0.274)$ & $0.70(0.562)$ \\
\hline & Nest (Species) & 43,22 & $2.51(0.011)$ & $4.12(<0.001)$ & $2.78(0.006)$ \\
\hline & $R^{2}(\%)$ & & 97.51 & 97.59 & 95.98 \\
\hline \multirow{6}{*}{$\begin{array}{l}\text { Finch-comparison between the two } \\
\text { regions of the outer nest and the cup } \\
\text { lining }\end{array}$} & Diameter (covariate) & 1,28 & $92.57(<0.001)$ & $89.50(<0.001)$ & $33.39(<0.001)$ \\
\hline & Species & 1,28 & $0.27(0.604)$ & $0.61(0.438)$ & $8.00(0.007)$ \\
\hline & Region & 2,28 & $1.42(0.258)$ & $1.30(0.289)$ & $1.06(0.359)$ \\
\hline & Species $\times$ Region & 2,28 & $2.11(0.140)$ & $2.49(0.101)$ & $3.02(0.065)$ \\
\hline & Nest (Species) & 15,28 & $1.37(0.228)$ & $1.12(0.388)$ & $1.17(0.345)$ \\
\hline & $R^{2}(\%)$ & & 97.93 & 97.85 & 97.03 \\
\hline
\end{tabular}

Values are $F$-values with $d f$ shown with $p$-values in parentheses

nests was found to still be significantly different between the two species (Table 3), with Hawfinches constructing nests composed of heavier materials per unit length than Bullfinches (Fig. 3).

\section{Discussion}

The distribution of materials within the birds' nests studied here was non-random in all species. The outer nests of all species were constructed of significantly thicker, stronger, more rigid and heavier materials than the cup 


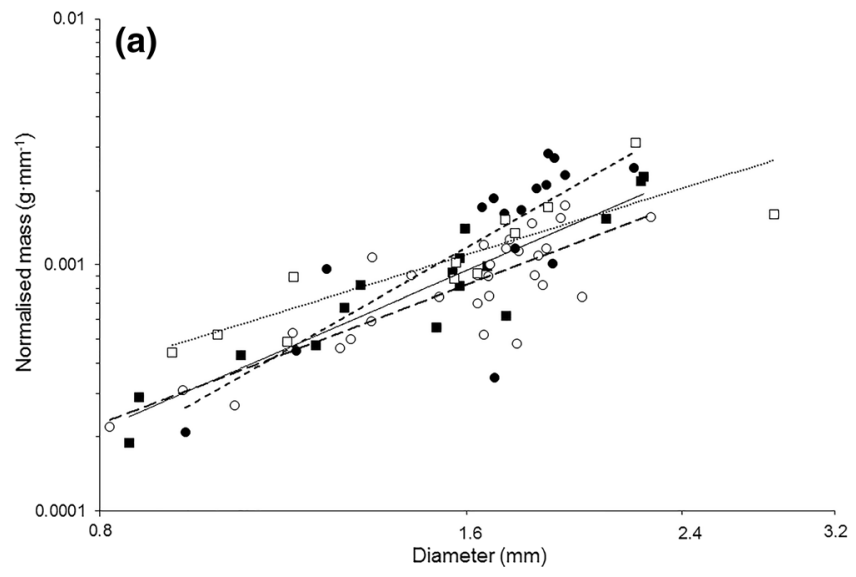

Fig. 3 Relationship between normalised mass and diameter of materials used in construction of the outer nests for a the four species of thrush-Common Blackbird (filled square, solid line), Song Thrush (open circle, dotted line), Mistle Thrush (filled circle, short dashed

linings. Whilst thrushes and Hawfinches placed the strongest materials in the top of the outer nest, Bullfinches placed them in the base of the outer nest and placed thinner less rigid materials around the top of the outer nest. All species that had a cup lining used thin, pliable materials.

As has been seen previously (Bocheński 1968; Biddle et al. 2015), all thrush nests had an outer nest and a mud cup, but a cup lining found in the nests of Ring Ouzels, Mistle Thrushes and Common Blackbirds was absent in Song Thrush nests. The values reported for the structural properties of materials in Common Blackbird nests were similar to those previously reported [Biddle et al. (2015), who studied a different sample of nests]. Bullfinches and Hawfinches built nests with very similar compositions to those reported previously (Bocheński and Oles 1981; Biddle et al. 2018).

Thrush nests could be identified by the proportions of different materials used in nest construction (Biddle et al. 2018). The exact nature of each piece of material sampled was not recorded in this study, but in most cases the outer nest materials were woody stems and the cup linings were mainly grass. There was, however, no difference in the structural properties of the materials used by the four thrush species to construct their nests. All exhibited significantly thicker, stronger and more rigid materials in the base of the outer nest, with thinner, weaker and less rigid materials in the top of the outer nest, as was previously reported for Blackbird nests (Biddle et al. 2015). Although Ring Ouzels nest on the ground, the use of materials in the nest base did not differ from those used by the tree-nesting species (Cramp 1988), which may reflect the fact that most thrush nests seem to be well supported from below (Simms 1978). This distribution of materials is considered to reflect the structural requirements of any thrush nest during construction, with thick, strong and rigid woody stems around the outside of

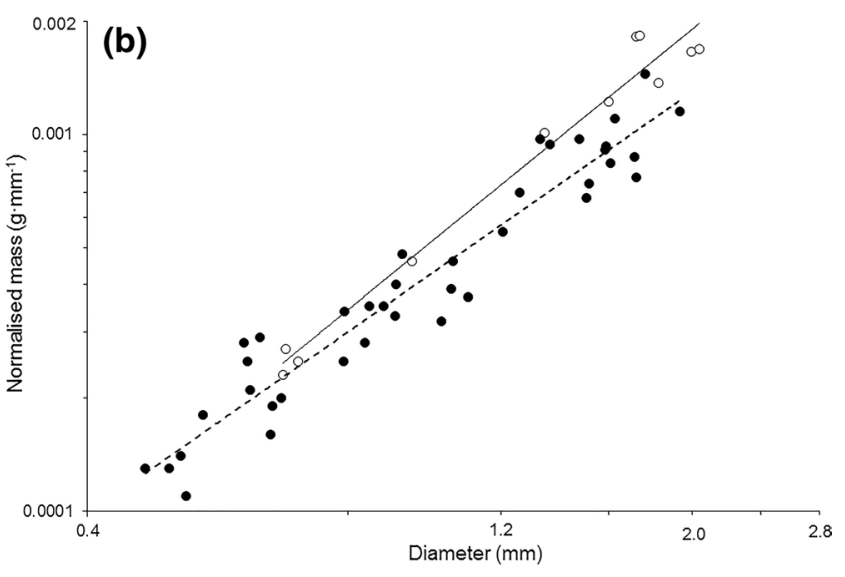

line) and Ring Ouzel (open square, long dashed line), and b two species of finch-Hawfinch (open circle, solid line), Bullfinch (filled circle, dashed line). Lines represent the line of best fit to indicate the trend. Note the $\log _{10}$ scales on the axes

the nest providing support during deposition of the mud cup (Biddle et al. 2015). The use of thinner, less rigid material in the cup may well reflect an insulative role for the materials (Mainwaring et al. 2014b), or they may provide a comfortable surface for nestlings (Hansell 2000) or room for expansion as they grow (Slagsvold 1989a, 1989b).

Mud cups are a characteristic of the nests of all European species of Turdus (Simms 1978) as well as the American Robin Turdus migratorius (Crossman et al. 2011), but are absent from the nests of Old World flycatchers and finches [Muscicapidae and Fringillidae, respectively (Biddle et al. 2018)]. The lower values for the structural properties observed in the base of the outer nest of the thrushes could be due to the presence of this mud cup. During nest construction Song Thrushes and American Robins have been seen constructing an outer nest using twigs and grasses to form a cup shape before lining the structure with wood pulp, mud or dung (Howell 1942; Goodfellow 2011). The presence of the mud cup is an additional structural element which is likely to significantly contribute to the nest's ability to support the adult bird and its clutch of eggs and nestlings. However, the structural properties of the outer nest, which would be needed to support the mud structure, are similar to those observed in the outer nest of finch nests, especially Hawfinch nests. Therefore, the materials present within the outer nest may provide a supporting 'foundation' framework during nest construction which may help support the nest structure until completion of the mud cup when it becomes less structurally important (Biddle et al. 2015).

During this study, we did not measure the mechanical properties of the mud cup or the materials present within it. This was due to the limited number of mechanically testable samples that were available, especially in the cup of Song Thrush nests, which was constructed largely of wood pulp. 
Also, polysaccharides present within saliva have been found to complicate the structural properties of the mud nests of Common House Martins (Silva et al. 2010). Although Song Thrushes are believed to mix saliva with the mud used within their cups (Bocheński 1968), it is not known whether this occurs in all species and is worthy of further study.

The structural characteristics of the materials used by finches differed between the species. In Hawfinch nests, as in thrush nests, the materials in the top of the outer nest were found to be the thickest, strongest, most rigid and heaviest within the nest, whilst the cup lining was composed of the thinner, weakest, least rigid and lightest materials. However, in Bullfinch nests, although the cup lining was comparable, it was the base of the outer nest that contained the thickest, strongest, most rigid and heaviest materials rather than the top of the outer nest (Biddle et al. 2017). This may reflect the heavier adult Hawfinches (Cramp 1988; Cramp and Perrins 1994), or the eggs or nestlings or the choice of nest site because Hawfinches tend to nest on flat branches next to tree trunks whereas Bullfinches tend to build nests in outer branches away from the trunk (Cramp and Perrins 1994). Such sites may offer differing support from below and may be reflected in the strength and rigidity of the materials used in the nest base. Interestingly, Horváth et al. (2015) showed that nests constructed high in trees by Rooks Corvus frugilegus, contain woody stems that average around $5 \mathrm{~mm}$ in diameter (range $2-15 \mathrm{~mm}$ ). This may reflect the much larger body mass of this corvid [420-490 g (Dunning 2008)]. Further research is needed to better understand nest construction in these and other species.

Qualitative reports (Ferguson-Lees et al. 2011) that suggest that nest construction patterns are species specific have been confirmed by studies that have quantified nest materials in a variety of species (see Deeming and Mainwaring 2015; Briggs and Deeming 2016; Biddle et al. 2017, 2018). Unfortunately, detailed descriptions of nest construction behaviour in birds are uncommon (Healy et al. 2015) and, for the species represented here, only available for the Song Thrush (Goodfellow 2011). Although structural characteristics of the materials strongly suggest that placement in different parts of the nest is non-random, it is not possible to categorically state that the birds select the materials that they place in different parts of the nest [see Biddle et al. (2017) for a discussion of this point]. It is possible that other factors impact on nest material collection behaviour. For instance, predation threat may impose a time restriction on the behaviour required to select nest materials, but further field research is generally needed to document this behaviour. However, Bailey et al. (2014) demonstrated that captive Zebra Finches had to first learn to choose stiffer rather than more flexible string samples to build their nests. Captive Zebra Finches have also been shown to select material based on colour (Muth et al. 2013). They also selected materials of different length to match the size of a nest box entrance hole, with their behaviour changing as nest-building proceeded; hence, their experience improved (Muth and Healy 2014). Laboratory-based studies using artificial nesting materials do not necessarily reflect the natural environment, so it would be interesting to see what choices are made when Zebra Finches are provided with more natural nesting materials. However, if captive birds are able to exhibit such discriminatory behaviour during nest construction then there is little reason to expect that wild birds could not do so too. Indeed, male Cape Weavers Ploceus capensis choose longer and stronger materials to build the outer nest before adding increasing shorter and weaker materials as nest-building progresses (Bailey et al. 2016). American Robins and Song Thrushes also change their behaviour by bringing in different materials at progressive stages of nest construction (Howell 1942; Goodfellow 2011). Therefore, if birds do exhibit decision-making during nest construction, on what basis could those decisions be made?

The diameter of materials was significantly different between the different nest regions in all species. Analyses suggested that variation of the structural properties of the materials used during nest construction was a function of the diameter of the materials in the different parts of the nest. Birds may select materials by assessing the diameter of a piece of material, perhaps in conjunction with its mass. Presumably such an assessment could be done by the birds by mandibulation of the material when it is first picked up. Thus, more rigid, stronger materials used in the outer nest may be chosen earlier in the nest construction phase because they are thicker and heavier. Later in the process weaker and more pliable materials that are suitable for the cup lining may be chosen because they are thinner and lighter. Behavioural studies, such as detailed observations of nest building or nest material-selection experiments, are required to confirm this idea. Therefore, we hypothesise that birds are not directly aware of the structural properties of the material per se, but rather assess diameter and mass of the material when it is picked up by the bill. Using this information the birds decide whether the piece is suitable for that particular stage of nest construction.

It is accepted that the materials recovered from different parts of the nest do not necessarily reflect nest construction behaviour. However, as has been argued elsewhere (Biddle et al. 2017), the data presented here do allow the formulation of testable hypotheses about how captive birds should respond if presented with materials with differing characteristics during nest building. Our understanding of nest construction behaviour is limited by a lack of data, and whilst recent studies have quantified the materials used by a variety of species (Briggs and Deeming 2016; Biddle et al. 2018), to date, very few species have been studied in detail. Future investigations into the mechanical properties of the 
materials used in nest construction should consider whether it is important to relate these to the weight of the clutch and parent. Understanding nest construction parameters in species with a greater range of body sizes would allow us to determine if larger species build nests from stronger materials. The Pine Grosbeak Pinicola enucleator is a finch comparable in mass to the Hawfinch, and also constructs an outer nest mainly from twigs (Pulliainen 1979), thus would be an ideal candidate for study. By contrast, finches smaller than the Bullfinch rarely use woody stems in their nests (Biddle et al. 2018). Small warblers (Sylvidae) and wagtails (Motacillidae) also rarely use woody stems in their nests (Dickinson, Locke, Goodman and Deeming, unpublished data 2018). Along with Rooks (Horváth et al. 2015) other corvids, e.g. Eurasian Jays Garrulus glandarius and Carrion Crows Corvus corone, are from two to five times heavier than thrushes and also build nests largely made of woody materials (Kulczycki 1973; Ferguson-Lees et al. 2011). Documenting the composition of such nests and testing the structural properties of the materials used in the different nest parts would allow us to test the idea that heavier birds use progressively thicker, stronger twigs, but only in some parts of their nests.

Acknowledgements All the authors conceived the project. L. E. B. collected the data; L. E. B. and D. C. D. analysed the data; and L. E. B. wrote the original manuscript, which was revised by D. C. D. and A. M. G. Many thanks go to Carl Barrimore and Dave Leech of the British Trust for Ornithology Nest Record Scheme for their assistance in publicising our need for bird nests, and we thank the numerous members of the scheme who generously supplied the nests used in this study. L. E. B. is grateful for the financial support from the School of Life Sciences, University of Lincoln.

Open Access This article is distributed under the terms of the Creative Commons Attribution 4.0 International License (http://creativeco mmons.org/licenses/by/4.0/), which permits unrestricted use, distribution, and reproduction in any medium, provided you give appropriate credit to the original author(s) and the source, provide a link to the Creative Commons license, and indicate if changes were made.

\section{References}

Álvarez E, Belda EJ, Verdejo J, Barba E (2013) Variation in Great Tit nest mass and composition and its breeding consequences: a comparative study in four Mediterranean habitats. Avian Biol Res 6:39-46

Bailey IE, Morgan KV, Bertin M, Meddle SL, Healy SD (2014) Physical cognition: birds learn the structural efficacy of nest material. Proc R Soc Lond B 281:e20133225

Bailey IE, Muth F, Morgan KV, Meddle SL, Healy SD (2015) Birds build camouflaged nests. Auk 132:11-15

Bailey IE, Morgan KV, Oschadleus HD, DeRuiter SL, Meddle SL, Healy SD (2016) Nest-building males trade off material collection costs with territory value. Emu 116:1-8

Barnes DM, Mallik AU (1996) Use of woody plants in construction of beaver dams in northern Ontario. Can J Zool 74:1782-1786
Biddle LE, Deeming DC, Goodman AM (2015) Morphology and biomechanics of the nest of the Common Blackbird Turdus merula. Bird Study 62:87-95

Biddle LE, Goodman AM, Deeming DC (2017) Construction patterns of birds' nests provide insight into nest-building behaviours. PeerJ 5:e3010

Biddle LE, Broughton RE, Goodman AM, Deeming DC (2018) Composition of bird nests is a species-specific characteristic. Avian Biol Res 11:132-153

Bocheński Z (1968) Nesting of the European members of the genus Turdus Linnaeus 1758 (Aves). Acta Zool Crac 13:349-439

Bocheński Z, Oles T (1981) Experimental studies on the nesting of Bullfinch Pyrrhula pyrrhula (Linnaeus, 1758) in aviaries. Acta Zool Crac 25:3-12

Briggs KB, Deeming DC (2016) Use of materials in nest construction by Pied Flycatchers Ficedula hypoleuca reflects localised habitat and geographical location. Bird Study 63:516-524

Britt J, Deeming DC (2011) First egg date and air temperature affect nest construction in Blue Tits Cyanistes caeruleus, but not in Great Tits Parus major. Bird Study 58:78-89

Cantarero A, López-Arrabé J, Moreno J (2015) Selection of nest site and nesting material in the Eurasian Nuthatch Sitta europaea. Ardea 103:91-94

Cramp S (1988) Handbook of the birds of Europe, the Middle East and North Africa. The birds of the Western Palearctic, Tyrant Flycatcher to thrushes, vol V. Oxford University Press, London

Cramp S, Perrins CM (1994) Handbook of the birds of Europe, the Middle East and North Africa. The Birds of the Western Palearctic, vol. VIII. Crows to finches. Oxford University Press, Oxford

Crossman CA, Rohwer VG, Martin PR (2011) Variation in the structure of bird nests between northern Manitoba and southeastern Ontario. PLoS One 6(4):e19086

Deeming DC (2016) How does the bird-nest incubation unit work? Avian Biol Res 9:103-113

Deeming DC, Mainwaring MC (2015) Functional properties of nests. In: Deeming DC, Reynolds SJ (eds) Nest, eggs, and incubation: new ideas about avian reproduction. Oxford University Press, Oxford, pp 29-49

Dhandhukia SN, Patel PK (2012) Selection of nesting sites and nesting material in Common Myna (Acridotheres tristis) in an urban area. Int J Pharm Life Sci 3:1897-1904

Dubiec A, Góźdź I, Mazgajski TD (2013) Green plant material in avian nests. Avian Biol Res 6:133-146

Dunning JB (2008) CRC handbook of avian body masses, 2nd edn. CRC, Baton Rouge

Ferguson-Lees J, Castell R, Leech D (2011) A field guide to monitoring nests. British Trust for Ornithology, Thetford

Fustec J, Cormier JP (2007) Utilisation of woody plants for lodge construction by European beaver (Castor fiber) in the Loire valley, France. Mammalia 71:11-15

Goodfellow P (2011) Avian architecture: how birds design, engineer and build. Princeton University Press, Princeton

Gordon JE (1978) Structures: or why things don't fall down. Penguin Books, London

Hansell MH (2000) Bird nests and construction behaviour. Cambridge University Press, Cambridge

Healy SD, Morgan KV, Bailey IE (2015) Nest construction behaviour. In: Deeming DC, Reynolds SJ (eds) Nest, eggs, and incubation: new ideas about avian reproduction. Oxford University Press, Oxford, pp 16-27

Hilton GM, Hansell MH, Ruxton GD, Reid JM, Monaghan P (2004) Using artificial nests to test importance of nesting material and nest shelter for incubation energetics. Auk 121:777-787

Horváth É, Solt S, Kotymán L, Palatitz P, Sándor Piross I, Fehérvári P (2015) Provisioning nest materials for Rooks; a potential tool for conservation management. Ornis Hunn 23:22-31 
Howell JC (1942) Notes on the nesting habits of the American Robin (Turdus migratorius L.). Am Midl Nat 28:529-603

Kulczycki A (1973) Nesting of the members of the Corvidae in Poland. Acta Zool Crac 17:583-666

Kull RC (1977) Color selection of nesting material by Killdeer. Auk 94:602-604

Mainwaring MC, Deeming DC, Jones CI, Hartley IR (2014a) Adaptive latitudinal variation in Common Blackbirds Turdus merula nest characteristics. Ecol Evol 4:841-851

Mainwaring MC, Hartley IR, Lambrechts MM, Deeming DC (2014b) The design and function of birds' nests. Ecol Evol 4:3909-3928

Moreno J (2012) Avian nests and nest-building as signals. Avian Biol Res 5:238-251

Moreno J, Martínez J, Corral C, Lobato E, Merino S, Morales J, Martínez-de la Puente J, Tomás G (2008) Nest construction rate and stress in female Pied Flycatchers Ficedula hypoleuca. Acta Ornithol 43:57-64

Muth F, Healy SD (2014) Zebra Finches select nest material appropriate for a building task. Anim Behav 90:237-244

Muth F, Steele M, Healy SD (2013) Colour preferences in nest-building Zebra Finches. Behav Proc 99:106-111

Pulliainen E (1979) On the breeding of the Pine Grosbeak Pinicola enucleator in NE Finland. Ornis Fenn 56:156-162
Silva B, Correia J, Nunes F, Tavares P, Varum H, Pinto J (2010) Bird nest construction-lessons for building with earth. WSEAS Trans Environ Dev 6:82-92

Simms E (1978) British thrushes. Harper Collins, London

Slagsvold T (1989a) On the evolution of clutch size and nest size in passerine birds. Oecologia 79:300-305

Slagsvold T (1989b) Experiments on clutch size and nest size in passerine birds. Oecologia 80:297-302

Surgey J, du Feu CR, Deeming DC (2012) Opportunistic use of a wool-like artificial material as lining of tit (Paridae) nests. Condor 114:385-392

Tomás G, Merino S, Martinez-de la Puente J, Moreno J, Morales J, Rivero-de Aguilar J (2013) Nest size and aromatic plants in the nest as sexually selected female traits in Blue Tits. Behav Ecol 24:926-934

Van Casteren A, Sellers WI, Thorpe SS, Coward S, Crompton RH, Myatt JP, Ennos AR (2012) Nest-building orang-utans demonstrate engineering know-how to produce safe, comfortable beds. Proc Natl Acad Sci USA 109:6873-6877

Vincent JVF (1992) Biomechanics-materials: a practical approach. 165-IRL Press at Oxford University Press, Oxford

\title{
Affiliations
}

\section{Lucia E. Biddle $^{1} \cdot$ D. Charles Deeming ${ }^{1} \cdot$ Adrian M. Goodman $^{1}$}

\author{
D. Charles Deeming \\ cdeeming@lincoln.ac.uk
}
Joseph Banks Laboratories, School of Life Sciences, University of Lincoln, Lincoln LN6 7DL, UK

